\title{
Znaczenie duchowości w pracy z osobami uzależnionymi od alkoholu
}

\section{Duchowość}

We współczesnym społeczeństwie nieustannie rośnie nieufność do instytucji religijnych i maleje udział wiernych w nabożeństwach i obrzędach. O prawdziwości tej tezy świadczy systematyczna ateizacja, nawet jeśli wyniki socjologiczne wskazują na niski wzrost ateizmu. Brak zaufania do instytucji nie stoi w sprzeczności z przekonaniami religijnymi, a spadek przynależności do nich nie oznacza słabnięcia wiary ${ }^{2}$.

W Europie powstaje nowy styl duchowości: wiara bez przynależności ${ }^{3}$ do instytucji religijnej. U podłoża tej sytuacji leży model sekularyzacji oraz przekonanie, że religijność przestaje być wartością priorytetową dla tożsamości współczesnej jednostki. Przy-

$1 \quad$ Ks. mgr lic. Artur Ciepielski - kapłan archidiecezji bratysławskiej, rekolekcjonista i psychoterapeuta. Doktorant na Wydziale Teologicznym Uniwersytetu Papieskiego Jana Pawła II w Krakowie. Aktywnie zaangażowany w prowadzenie spotkań formacyjnych grup Faustinum na Słowacji.

2 Por. G. Davieová, Výjimečný prípad Evropa. Podoby víry v dnešním světě, Brno 2009, s. 207.

3 Por. G. Davieová, Výjimečný př́pad Evropa, dz. cyt., s. 18-19. 
czynę tego zjawiska socjologia religii upatruje w indywidualizacji stylu życia człowieka ${ }^{4}$. Tożsamość religijna stała się sprawą ściśle prywatną, co niewątpliwie jest wynikiem rozwoju historii Europy. Rosnący wpływ indywidualizacji osłabia zaś zainteresowanie życiem duchowym i religijnym. Wysoko rozwinięty konsumpcjonizm zmusza do nieustannego podejmowania decyzji i wyborów towaru, usług, przyjaciól, ale również i tożsamości osobistej. Tożsamość przybiera charakter zadania, które człowiek musi rozwiązywać na płaszczyźnie decyzji. Subiektywny wybór jest jednak uzależniony od grup społecznych, tradycji, ale również od społecznych i osobistych doświadczeń.

Osoba jako jedność biopsychospołeczna rozwija się na wielu płaszczyznach swojego człowieczeństwa. Jednym z obszarów tego rozwoju jest sfera duchowa, która wspiera człowieka w jego myśleniu i działaniu. Jako ważny czynnik rozwoju osobistego wpływa na poczucie sensu życia i pomaga w rozwiązywaniu problemów, ze szczególnym uwzględnieniem natury duchowej i psychicznej. $\mathrm{Z}$ tego powodu religia i psychoterapia stają się dla siebie coraz bliższe w nadawaniu sensu życia ludzkiego i formowaniu hierarchii wartości.

Autor rozumie duchowość współcześnie, jako element osobowości, który powstaje poprzez scalenie istniejącego sacrum, pogłębienie relacji do niego oraz prezentowanie go w różnych sytuacjach życia. Poczucie niezwykłości sfery sacrum trafnie uświadamia człowiekowi jego ograniczenia, uczy je szanować oraz respektuje te sytuacje i czynniki, które powodują ich przekraczanie ${ }^{5}$. Etymologicznie słowo „duchowość” pochodzi od łacińskiego słowa spiritus lub spiritualis. Wywodzi się ono od czasownika spirare, który oznacza oddychanie. Dlatego też jest tłumaczone jako „oddech” lub „duch”,

4 Por. D. Václavík, Náboženství a moderní česká společnost, Praha 2010, s. 256.

5 Por. J. Křivohlavý, Pozitivní psychologie, Praha 2010, s. 200. 
a spiritualis jako „duchowy”. W świetle semantyki duchowość jest koncepcją bardzo pluralistyczną i posiada szeroki zakres znaczeniowy. Koncepcja duchowości rozumiana jako świadomość sacrum była znana już w starożytności. Jordan Aumann twierdzi, że te potrzeby duchowe człowieka charakteryzowały się kultem religijnym $^{7}$. Życie duchowe Słowian było skoncentrowane na kulcie wielu bogów. Poganie dzięki konwersji na wiarę chrześcijańską zostali uwolnieni od strachu przed siłami wyższymi, które miały wpływać na życie codzienne, rozwój rolnictwa i inne ${ }^{8}$.

W chrześcijańskiej historii duchowości jej rozwój przybliża działanie trzeciej osoby Boskiej, które przejawia się w różnych aspektach życia duchowego. Różnorodność ta znajduje odzwierciedlenie w sposobach naśladowania Jezusa. Historia pojęcia „duchowość” sięga średniowiecza, ale sens znaczeniowy przypisywany mu dzisiaj pochodzi z przełomu XIX i XX wieku. Duchowość chrześcijańska łączy się z konkretnym sposobem życia oraz wartościami pozwalającymi na harmonizowanie życia wiary z modlitwą, kontemplacją, sakramentami. Wszystko to dzieje się dzięki Duchowi Świętemu, który prowadzi człowieka do doświadczenia miłości' ${ }^{9}$ Szeroko rozumianą duchowość można rozważać w jej różnych obszarach, odkrywając jej odmienne źródła, pochodzenie i rozwój. Poza płaszczyzną wiary i tradycji religijnej źródłem duchowości mogą być: wiedza, sztuka, sport, doświadczenia, przyroda czy relacje międzyludzkie. Najważniejsze jest jednak to, jak człowiek rozumie sacrum i jak do niego podchodzi. Subiektywne podejście nie ma uniwersalnego i niezmiennego charakteru, ale odzwierciedla się w konkretnych sytuacjach życia ludzkiego.

9 Por. S. de Fiores, T. Coffi, Slovník spirituality, dz. cyt., s. 51-906. 
Przeżywanie duchowości wpływa na koncepcję osobowego postrzegania sacrum i wyrażania go poprzez emocje, relacje do drugiego człowieka i w stosunku do siebie oraz do samego sacrum. Koncepcja uzewnętrznia się w rozwoju osobowym człowieka, w jego akceptacji własnych ograniczeń, w szukaniu miejsca w świecie, w zachowaniu względem drugich. Konkretnym obszarem jej realizacji są różnego rodzaju rytuały życia codziennego, do których należą również i te duchowe. Fundamentem życia są normy i wartości, przyjęte jako zasady moralne zapewniające prawdziwość postępowania i gwarancję bezpieczeństwa. Osobiste przeżywanie duchowości prowadzi do najważniejszego doświadczenia, jakim jest doświadczenie bliskości Boga.

\section{Uzależnienie}

Uzależnienie w życiu człowieka oddziałuje na wielu poziomach: fizycznym, psychicznym, społecznym i duchowym. Silnie dewaluuje osobę uzależnioną, nie tylko w jej indywidualnym byciu - wpływa też na całe jej otoczenie. Pomoc w leczeniu uzależnień jest wielopłaszczyznowa. Program terapii musi więc obejmować wspólne relacje na poziomie somatycznym, psychicznym, społecznym oraz duchowym.

Pomoc osobom uzależnionym również na poziomie duchowym nie jest nowym zagadnieniem w terapii uzależnień. Już Carl Gustav Jung widział w kryzysach duchowych jedną z wielu przyczyn powstania uzależnienia ${ }^{10}$. Podobnie argumentował Viktor Emil Frankl, twierdząc, że frustracja egzystencjalna ma udział w powstaniu uzależnienia ${ }^{11}$. Również Wallace uważa, że pustka wewnętrzna, utrata sensu i celu życia są impulsem dla zaistnienia i kontynuacji 
uzależnienia ${ }^{12}$. Poziom duchowy jest użyteczny w procesie leczenia, ponieważ podkreśla potrzebę posiadania sensu życia, wartości duchowych i istnienie autorytetu duchowego. Czynniki te są ważne nie tylko na początku, ale i w czasie leczenia, jak również po jego zakończeniu ${ }^{13}$.

Uzależnienie ma silny wpływ na psychiczne procesy zachodzące w życiu człowieka. Do nich należą także procesy poznawcze. Działanie alkoholu wpływa na sferę uczuć, woli i zachowań, stwarzając również świat wirtualny, w którym uzależniony czuje się bezpiecznie, gdyż buduje nową tożsamość, pozbawioną realnej rzeczywistości i odpowiedzialności. Uzależnienie staje się stanem uwolnienia od zewnętrznych (szukanie miejsca w świecie, wymagania egzystencjalne i profesjonalne) i wewnętrznych (poczucie niższości, nieprzyjęcie własnej osoby, niespełnienie snów i ideałów, brak sił, choroby) wpływów oddziaływujących na człowieka. U osób w podeszłym wieku wypełnia pustkę i znudzenie życiem. Na płaszczyźnie wspólnotowej szczególnie alkohol deformuje relacje, usuwa bowiem bariery i wprowadza uczucie dobrej atmosfery, akceptacji, ale może również prowadzić do napięć i nieporozumień. Przebywanie poza światem realnym nieraz przyczynia się także do całkowitej izolacji. Uzależnienie może się stać normą ludzkiego życia i celebracją zachowań, które z niego wypływają. Przyjemne doświadczenia motywują do pogłębiania własnej sytuacji, oderwania od rzeczywistości i wykreowania duchowości pochodzącej z nałogu, która nie przynosi trwałych rozwiązań i nie wspiera, ponieważ nie jest realna.

Na płaszczyźnie somatycznej duchowość ułatwia osobie uzależnionej zrozumieć i przyjąć zagubione wartości zdrowia i troski o niego, pomaga pojąć sens bólu i cierpienia. Na poziomie psychiki interpretuje własną wartość osoby, jej rozumienie, i ukazuje

12

13

Por. J. Wallace, Teorie modelu 12 kroků, Praha 1999, s. 17-34.

Por. S. Kudrle, Bio-psycho-sociálně-spirituální model závislosti k primární, sekundární a terciárni prevenci a kvalifikované pomoci, Praha 2008, s. 17-23. 
miejsce człowieka w świecie. Uczestniczy w rozwoju osobowości, usamodzielnieniu, przyjęciu zadań i kształtowaniu tożsamości. Pozwala zweryfikować, iż sytuacja życiowa, w jakiej znajduje się osoba uzależniona, wynika $\mathrm{z}$ jej nałogu, nie jest realna i nie przynosi zadowolenia. Na płaszczyźnie socjalnej duchowość wspiera integrację ze społeczeństwem oraz pomaga przyjąć normy postępowania akceptowane społecznie. Przeżywany na nowo proces socjalizacji człowieka uzależnionego może pomóc mu otworzyć się na różne możliwości procesu leczenia, które przede wszystkim zorientowane są na zmianę. W przypadku uzależniania od alkoholu nie chodzi o natychmiastowe zwycięstwo, ale o długotrwały proces i zaangażowanie człowieka we wprowadzanie w życie zmian nabytych systematyczną pracą. Dla stworzenia bezpiecznego i inicjatywnego środowiska abstynencji, gdzie wypracowuje się trwałe zmiany myślenia i zachowania, jako wsparcie może posłużyć poradnictwo i psychoterapia.

Poradnictwo jest dla uzależnionego wsparciem w rozwiązywaniu nieprzepracowanych sytuacji życiowych. Ta forma pomocy według celowości i kompetencji obejmuje udzielanie potrzebnych informacji dla dojrzałego i krytycznego podejścia do przeżywanego problemu. Jest też wstępem do psychoterapii, ukierunkowanej na osiąganie zmian osobowości - myślenia, emocji, zachowań i charakterystyki osobowościowej - przy pomocy dostępnych środków, komunikacji i relacji. Podstawą działania na tych płaszczyznach jest motywacja ze strony uzależnionego i współpraca w procesie leczenia ${ }^{14}$. Motywacja jako punkt wyjścia otwiera człowieka na nowe poznanie i nowe możliwości życiowe. Poradnictwo może być wykorzystywane w sytuacjach, kiedy uzależniony ma słabą motywację do zmiany i jest w stanie aktywnego uzależnienia. W procesie 
leczenia ważna jest również edukacja bliskich i rodziny uzależnionego, którzy mają być dla niego pomocą i wsparciem. Poradnictwo duchowe według dzisiejszych zasad obejmuje jednorazowe lub krótkotrwałe wsparcie po długoterminowym oddziaływaniu na uzależnionego, szukanie i poznanie jego możliwości rozwoju. Nie ogranicza się tylko do tradycji duchowości, ale jest otwarte na pluralizm. Wymaga to od doradcy duchowego szerokiej orientacji religijnej. Jego osobiste doświadczenie życia może być pomocą w nawiązaniu relacji terapeutycznych ${ }^{15}$.

Psychoterapia zawsze była elementem życia ludzkiego. W człowieku jest żywe pragnienie zrozumienia siebie, otaczającego świata oraz odnalezienia w nim swojego miejsca i zadań do spełnienia. $\mathrm{W}$ ten sposób psychoterapia staje się bliska filozofii i teologii nie tylko w sferze teoretycznej, ale i praktycznej. Duchowość wyraża się i w psychoterapii ${ }^{16}$; tego powodu osobista refleksja psychoterapeuty pozytywnie wpływa na zrozumienie problemu klienta. Spojrzenie na uzależnienie z punktu widzenia duchowości stwarza możliwość zbliżenia się do duchowych potrzeb uzależnionego i ukierunkowania go na szukanie źródła życia wolnego. Aby uzależniony mógł prowadzić niezawisłe życie, musi zmienić sposób myślenia i postępowania. Psychoterapia z poradnictwem przy współpracy ze strony uzależnionego mogą wytworzyć bezpieczne środowisko dla zaistnienia tych zmian. Duchowość budująca na położonym fundamencie pozytywnie wpłynie na rozwój osobowości człowieka, a więc i na jego zmianę.

\section{Duchowe metody terapeutyczne}

Duchowość jest intymną relacją do tego, co nas przewyższa, co jest dla nas autorytetem, prawem, ideałem, nadającą sens codzien-

15 Por. Z. Vojtíšek, Duchovní poradenství v multikulturní společnosti, Praha 2008, s. 141154.

16 Por. K. Nešpor, Zůstat stř̌zlivý, dz. cyt., s. 134. 
nym dążeniom ${ }^{17}$. W przypadku uzależnień duchowość rozumie się jako indywidualną intensywność ludzkich potrzeb, jako drogę do osiągnięcia wartości osobowości: pokoju, mądrości i sensu życia. Może być prezentowana przez różne obrzędy i doświadczenia duchowe. Doświadczenia mogą wypływać z życia duchowego, szczytów przeżywania emocji, zauroczenia przyrodą, sztuką lub z wielu innych sytuacji i przeżyć. Duchowość jest silnie zakorzeniona w religijności, która oddziałuje na życie człowieka wierzącego. Rozwój duchowości ma pozytywny wpływ na zdrowie jednostki i podnosi jakość życia. Pozytywny wpływ naturalnego rozwoju duchowego człowieka odzwierciedla się w sposobie i zdolności radzenia sobie z problemami. Psychoterapia ukierunkowana na rozwój duchowości pomyślnie przyczynia się do procesu zmian w strukturze osobowości. Podczas terapii uzależnionych od alkoholu wykorzystuje się 12 kroków i 12 tradycji, które wywodzą się z duchowości chrześcijańskiej. Duchowość ma duże znaczenie w terapii uzależnień. Interwencje terapeutyczne muszą respektować wiarę klienta i jego potrzeby duchowe ${ }^{18}$.

Uzależnienia negatywnie wpływają na życie duchowe człowieka. U wielu ludzi nadmierne picie alkoholu osiąga swoją kulminację w uczuciach osądzania, izolacji, pustki oraz straty istoty i wartości życia. Niedające się przewidzieć zachowania prowadzą do kompromitowania wyznawanych wartości moralnych. Niepewność i zamęt z powodu uzależnienia przynoszą poznanie ograniczeń osobowości. O sytuacji uzależnionych od alkoholu mówi stwierdzenie, że są ludźmi podobnymi do łodzi bez sternika na wzburzonym morzu. Alkoholicy opisują przykre doświadczenia duchowe występujące w trakcie aktywnego picia, charakteryzujące się uczuciem pustki i deficytu wartości życia. Rozpacz z powodu stanu bezsilności

17 S. 91.

18

Por. S. Kudrle, Úvod do bio-psycho-socio-spirituálního modelu závislosti, Praha 2003,

Por. P. Doležalová, Spiritualita a zdraví při léčbě závislostí, Praha 2005, s. 286. 
może być prowokacją do ponownego picia. Nic tak nie napełnia pustki uzależnionego jak alkohol ${ }^{19}$.

\section{Hagioterapia}

Hagioterapia jest formą psychoterapii egzystencjalnej i opiera się na pracy terapeutycznej z tekstami biblijnymi. Nazwa terapii wywodzi się od greckiego przymiotnika hagios, tłumaczonego jako „święty”, i odzwierciedla charakter tekstu, z którym się pracuje. Nie chodzi więc o osiąganie stopnia doskonałości, ale o zrozumienie wartości życia człowieka, które jest święte, i takiego podejścia do życia, aby nie umniejszać jego znaczenia. Biblia jako przedmiot terapii ilustruje struktury psychiczne ściśle połączone z duchowością. Uzależnieni często nie znają podstawowych kwestii dotyczących sensu życia i hierarchii wartości. Dlatego celem hagioterapii jest umocnienie dojrzałych struktur psychicznych. Koncepcja bezpośrednio odnosi się do płaszczyzny norm i wartości. Drugoplanowy cel stanowi zmiana: ze sposobu życia ukierunkowanego na niespokojne pragnienie tego, czego człowiek nie ma, na życie w radosnej wdzięczności za to, co człowiek posiada. Erich Fromm charakteryzuje te dwa sposoby życia jako mieć i być. Prokop Remeš porównuje te sposoby do dwóch dróg: mieć to droga ekonomiczna, zaś być - duchowa ${ }^{20}$. Ich odrębność jest w terapii niezbędna.

Historie biblijne działają w terapii na płaszczyźnie fabuły. Biblię w hagioterapii postrzega się jako zwierciadło ludzkiego wnętrza. Takie podejście ma swoje podstawy w tradycji i skupia się na charakterze czytelnika i jego własnych doświadczeniach. Wspólnota odgrywa ważną rolę, ponieważ terapia odbywa się na spotkaniach grupowych, gdzie uczestnicy siedzą w kręgu, tak aby się widzieli

\footnotetext{
19 Por. J. Wallace, Teorie modelu dvanácti kroků, Praha 1999, s. 21.

20 Por. P. Remeš, Psychoterapeutické aspekty biblických př́běhů, Praha 2004, s. 200.
} 
i czuli wspólną bliskość. Po wstępnych procedurach charakteryzujących terapie grupowe trzykrotnie czyta się tekst biblijny, a uczestnicy aktywnie koncentrują się na przeżywaniu emocji, które tekst wywołał. Po przeczytaniu następuje werbalizacja najsilniej przeżywanych poruszeń, a następnie gniewu. Uczucie gniewu wypływa $\mathrm{z}$ naszego świata wewnętrznego i ze sposobu postrzegania. Potem uczestnicy dzielą się indywidualną refleksją na temat wysłuchanego tekstu. Grupa kończy wspólne spotkanie modlitwą w celu umocnienia członków do przeżywania dalszych dni. Uczestnicy doświadczają działania tekstu i grupy. Na poziomie osobistym uczestnik może przeżyć oddziaływanie tekstu, a grupa doświadczenie, na podstawie wyjaśnienia własnego zachowania albo odniesienia do faktów. Doświadczenia z grupy wyrażają indywidualną i wspólnotową płaszczyznę rozumienia Boga, Jego woli i czynów prezentowanych w tekście.

Hagioterapia jest kreatywnym, literackim oddziaływaniem tekstu, jak również symboliką poszczególnych postaci z tekstu wyrażonych uczestnikami grupy na płaszczyźnie osobistego przeżywania treści.

\section{Ikonoterapia}

We współczesnej społeczności coraz rzadziej można spotkać się z rzemiosłami, które prezentują nie tylko wartości artystyczne jednostki, ale przede wszystkim jej samorealizację. Znikome są wyniki dzisiejszej działalności człowieka, będącego częścią anonimowej całości. $\mathrm{Z}$ tych powodów psychologia, pedagogika, psychoterapia i inne nauki o nim ujawniają potrzebę pomocy dla efektywnej samorealizacji. Na wyżej wymienionych wartościach opiera się arteterapia.

Nieoficjalnym założycielem arteterapii jest grecki filozof Arystoteles, który jako pierwszy próbował badać więzi emocjonalne w relacjach do sztuki ${ }^{21}$. Arteterapia to zbiór metod i technik artystycznych, 
których podstawową funkcję stanowi pozytywne oddziaływanie na człowieka w celu zmiany formy i treści jego introspekcji, podniesienia własnej wartości i pomocy w spełnieniu życia ${ }^{22}$. Często $\mathrm{w}$ diagnostyce psychologicznej są wykorzystywane różnego rodzaju wyrażenia artystyczne. Prezentują one proste uzewnętrznianie uczuć i emocji oraz nieinwazyjny sposób odkrywania najbardziej intymnych sfer życia wewnętrznego. Proces tworzenia dzieł pomaga człowiekowi odizolować się od stanów chorobowych i natchnąć go nową ochotą do życia. Z tego powodu arteterapia jest właściwą metodą wspomagającą leczenie pacjentów psychotycznych, niepełnosprawnych i z zaburzeniami emocjonalnymi. Zachęca ich do odreagowania i wyrażania swoich uczuć poprzez symboliczny i niewerbalny język, który sami uczą się systematycznie rozumieć. Oprócz wykonywanych czynności częścią tej techniki jest również rozmowa. Celu tej metody nie stanowi zdobycie zdolności artystycznych, ale spontaniczne formowanie obiektów artystycznych prezentujących przeżywane emocje. Dlatego arteterapia jest rozumiana jako metoda lecznicza i rehabilitacyjna.

Jedną ze sfer arteterapii stanowi ikonoterapia. Autorem prezentowanego modelu jest psycholog i ksiądz prawosławny Milan Týmal, który ją wykorzystywał w terapii uzależnień. Týmal twierdził, że praktykowana przez niego forma ma swoje źródło w prawosławnej antropologii teologicznej, która definiuje człowieka w trzech płaszczyznach - są to ciało, dusza i duch. Według tej teorii człowiek jest zakorzeniony w ziemi, psychiką upodabnia się do Boga, a duchem go odzwierciedla. Jest to idealny stan, ale na skutek upadku pierwszego człowieka, Adama, człowiek odwraca się i kieruje ku upadkowi i zamiast odzwierciedlać Boga, wyraża ludzką duszę i materię. W tej sytuacji przychodzi na pomoc ikonopiśmiennictwo. Ikony w chrześcijaństwie wschodnim nie są obrazami religijnymi albo 
dziełami artystycznymi, ale oknem, które otwiera duszy ludzkiej spojrzenie na Boże otoczenie. Ta właśnie różnica najbardziej działa na motywację człowieka. Przedstawiona koncepcja teologiczna jest obrazem terapeutycznym w procesie leczenia uzależnień, odzwierciedlającym przejście od wartości uzależnienia do wartości najwyższej - Boga ${ }^{23}$.

W terapii jest wykorzystywana ikona Trójcy Świętej Andrieja Rublowa. Na podstawie doświadczeń kompozycja trzech postaw przy stole stwarza możliwość dla czwartego gościa. Uczestnicy terapii są zaproszeni do kontemplacji ikony, wejścia w jej przestrzeń, słuchania śpiewu chórowego, i są instruowani o wolnym sposobie myślenia. Po upływie 5-30 minut następuje druga część spotkania w formie refleksji, polegająca na rozmowie indywidualnej. Uczestnicy oprócz refleksji nad emocjami są motywowani do egzystencjalnego spojrzenia na własne życie, uświadomienia sobie własnej winy, istnienia hierarchii wartości, dobra, zła, Boga, śmierci ${ }^{24}$.

Ikonoterapia jest formą, która znajduje się w procesie nieustannego rozwoju. Możliwości wykorzystania motywacji na fundamencie duchowym można aplikować u klientów mających predyspozycje duchowe, będących wierzącymi. Emocje i ich wpływ na osobowość człowieka obserwuje się również u ludzi niemających podstaw duchowych. Trzeba jednak liczyć się z tym, że niewłaściwe aplikowanie wartości duchowych może skomplikować proces motywacyjny. Zaletą terapii jest fakt, że klient potrafi sam osiągnąć podstawowy kierunek, bez wpływów zewnętrznych ${ }^{25}$. Można stwierdzić jej pozytywny wpływ na stan emocjonalny człowieka. Ikonoterapia prezentuje się jako produktywna forma terapeutyczna, ale podobnie jak w każdym procesie leczniczym i w niej istnieje przestrzeń

23 1999, s. 220-223.

24

25
Por. O. Čačka, Psychologie imaginativní.., dz. cyt., s. 220-223.

Por. O. Čačka, Psychologie imaginativní.., dz. cyt., s. 220-223. 
na eksperymentalne weryfikacje i usystematyzowanie. W tym kontekście można ją aplikować nie tylko w przypadku uzależnień, ale również $\mathrm{w}$ innych indykacjach lub problemach. Nie ma przeciwwskazań, aby mogła być praktykowana przy depresjach, frustracjach lub odmiennych stanach emocjonalnych. Wciąż istnieje możliwość wykorzystania różnych rodzajów ikon, według wyboru klienta lub zaleceń terapeuty. Takie podejście można zaproponować także członkom innych tradycji duchowych. W ramach praktyk terapeutycznych zaleca się wprowadzenie możliwości pisania ikon. Wyeksponowanie wartości emocjonalnych w dziełach zawiera w sobie bogaty potencjał diagnostyczny i terapeutyczny. Maksymalizacja potencjału byłaby możliwa przez wprowadzenie do terapii wymiaru duchowego.

\section{Logoterapia}

Twórcą logoterapii jest austriacki psychiatra Viktor Emil Frankl, a metodę tę nazywa się trzecią wiedeńską szkołą psychoterapeutyczną. Za wcześniejsze uważa się psychoanalizę Sigmunda Freuda i psychologię indywidualną Alfreda Adlera. Jej nazwa pochodzi od greckiego rzeczownika logos, który bywa tłumaczony jako słowo. Logoterapia nie jest tylko metodą psychoterapeutyczną, ale ma również swoje odniesienie do aspektów filozofii i teologii. Podstawy teorii Frankla są zakorzenione w jego doświadczeniach $\mathrm{w}$ pracy z młodzieżą w klinice neuropsychiatrycznej w Wiedniu, gdzie uświadomił sobie uczucie pustki i bezsensu życia ludzi niezatrudnionych. Swoją teorię pogłębił w czasie pobytu w obozie koncentracyjnym podczas II wojny światowej. Przedmiotem jego koncepcji jest człowiek jako całość, nie zajmuje się on wyodrębnionymi aspektami osobowości. Ważny element logoterapii stanowi nieustannie pogłębiający się proces odnajdywania sensu życia $\mathrm{w}$ różnych sytuacjach. Istota życia wypływa z wymiaru duchowego, który nie musi mieć swoich podstaw w religii. Od człowieka zale- 
ży, w jakiej mierze sens jego życia ma charakter religijny ${ }^{26}$. Frankl widzi w uczuciu bezsensowności źródło i przyczynę wielu problemów. Stan, w którym ludzie nie wiedzą, co mają robić ze swoim życiem, może być przyczyną zachowań patologicznych oraz uzależnień. Prowadzi on do frustracji egzystencjalnej, którą Frankl określa jako vacuum egzystencjalne. Stan pustki można charakteryzować w kategoriach napięć i braku. Człowiek nie jest zdolny odnieść się do treści egzystencjalnych na płaszczyźnie intelektualnej i emocjonalnej, będących motywacją dla jego życia osobowego. Przyczynę powstania vacuum widzi w tym, że w odróżnieniu od zwierząt nie kierujemy się instynktami, które mówią nam, co mamy robić. Współczesny, nowoczesny człowiek jest niewrażliwy na tradycję, mówiącą o działaniach z przeszłości, dlatego w konsekwencji nie wie, czego chce. Frustracja egzystencjalna może się przerodzić w noogenną neurozę ${ }^{27}$, w której logoterapia jest pomocą psychoterapeutyczną.

Ludzką egzystencję według Frankla charakteryzują trzy fenomeny: duchowość, wolność i odpowiedzialność. Duchowość jest fenomenem należącym do podstawowego wyposażenia człowieka od początku jego istnienia. To podstawa i gwarancja jedności psychicznej, fizycznej i duchowej człowieka. Wymiar duchowy egzystencji ściśle łączy się z ludzką religijnością. Chodzi o głębokie doświadczenie religijne i przeżycia połączone z sacrum, pomimo że w świadomym życiu człowieka nie było dla nich miejsca. Nieświadoma duchowość odsłania religijność jednostki. Logoterapia otwiera się na wartości duchowe i argumentuje, że usuwanie treści religijnych ze świadomości człowieka nie rozwiązuje problemów, ale jest spychaniem ich w podświadomość duchową, co może wyrażać się w konflikcie sumienia. Wolność jako fakt egzystencji osobowej

Por. V. J. Drapela, Přehled teorií osobnosti, Praha 2011, s. 145-147.

27 Por. V. E. Frankl, Lékařská péče o duší. Základy logoterapie a existenciálníanalýzy, Brno 1996, S. 25-31. 
jest w teorii Frankla podstawą i warunkiem prowadzenia jakiejkolwiek psychoterapii. Ten stan można osiągnąć na podstawie wolności osobowej - to nie wolność od czegoś, ale do czegośn ${ }^{28}$. Człowiek wprawdzie nie jest oswobodzony od popędów, ale one nie stanowią istoty jego życia. Wolność łączy się z wyborami i podejmowanymi decyzjami. $Z$ tego powodu istota ludzka jest odpowiedzialna za to, co wybiera. Logoterapia wywodzi się z analizy egzystencjalnej. Jej celem jest doprowadzenie człowieka do uświadomienia sobie odpowiedzialności jako podstawy ludzkiej egzystencji. Odpowiedzialna egzystencja podejmuje możliwość realizacji wartości będących dla człowieka nieustannym zadaniem, zmieniającym się w czasie, ale zawsze mającym sens. Podstawowe aspekty logoterapii są wykorzystywane w procesach leczniczych uzależnień, również uzależnień od alkoholu. Trzeba jednak pamiętać, że logoterapia, podobnie jak inne metody, nie jest całkowicie uniwersalna w stosunku do człowieka - osobowości zupełnie indywidualnej, z subiektywnym przeżywaniem. Wyniki terapeutyczne określają ją jako metodę psychoterapeutyczną odpowiednią dla problematyki uzależnień.

\section{Wspólnota Anonimowych Alkoholików (AA)}

U początków powstania wspólnoty terapeutycznej Anonimowych Alkoholików stał uczeń Sigmunda Freuda, twórcy psychoanalizy, Carl Gustav Jung. Jung zajmował się leczeniem pacjenta uzależnionego od alkoholu, niestety próba ta zakończyła się po roku bez pozytywnych wyników. Polecił mu, aby zaczął szukać pomocy w wierze. Pacjent, otwarty na tę propozycję, przeżył nawrócenie i stał się chrześcijaninem, co miało pozytywny wpływ na jego abstynencję. Swoimi doświadczeniami dzielił się z innymi uzależnionymi, 
w czego konsekwencji Bill Wilson, trzeźwiejący alkoholik, stał się inicjatorem ruchu Anonimowych Alkoholików. Wilson sformułował również podstawy wspólnoty i zawarł je w zbiorze zaleceń pod nazwą 12 kroków ${ }^{29}$. Rewolucja, jaką wywołało powstanie ruchu Anonimowych Alkoholików, nie jest w medycynie jeszcze doceniona. Powstanie go doprowadziło do sytuacji, w której personel medyczny zaczął traktować pacjentów jako partnerów i współpracowników. Anonimowi Alkoholicy powstali wcześniej niż pierwsze grupy terapeutyczne ${ }^{30}$.

Oto treść poszczególnych kroków:

1. Przyznaliśmy, że staliśmy się bezsilni wobec alkoholu - że przestaliśmy kierować własnym życiem.

2. Uwierzyliśmy, że siła większa od nas samych może przywrócić nam zdrowy rozsądek.

3. Postanowiliśmy powierzyć naszą wolę i nasze życie opiece Boga, jakkolwiek Go pojmujemy.

4. Zrobiliśmy gruntowny i odważny obrachunek moralny.

5. Wyznaliśmy Bogu, sobie i drugiemu człowiekowi istotę naszych błędów.

6. Staliśmy się całkowicie gotowi, aby Bóg uwolnił nas od tych wszystkich wad charakteru.

7. Zwróciliśmy się do Niego w pokorze, aby usunął nasze braki.

8. Zrobiliśmy listę wszystkich osób, które skrzywdziliśmy, i staliśmy się gotowi zadośćuczynić im wszystkim.

9. Zadośćuczyniliśmy osobiście wszystkim, wobec których było to możliwe, $\mathrm{z}$ wyjątkiem tych przypadków, gdy zraniłoby to ich lub innych.

10. Prowadziliśmy nadal obrachunek moralny, z miejsca przyznając się do popełnianych błędów. 
11. Dążyliśmy poprzez modlitwę i medytację do coraz doskonalszej więzi z Bogiem, jakkolwiek Go pojmujemy, prosząc jedynie o poznanie Jego woli wobec nas oraz o siłę do jej spełnienia.

12. Przebudzeni duchowo w rezultacie tych kroków, staraliśmy się nieść to posłanie innym alkoholikom i stosować te zasady we wszystkich naszych poczynaniach ${ }^{31}$.

Bill Wilson w swoim dziele Opowieść charakteryzuje podstawowe koncepcje, które pomogły mu zwyciężyć nad alkoholem, a które sformułowane zostały w 12 krokach. Stały się one fundamentem dla Anonimowych Alkoholików, którą wprowadzają w życie w pierwszej osobie liczby mnogiej. W ten sposób czytelnik jest w tych koncepcjach obecny i przez nie ubogacony. Teoria Billa i dr. Boba ma podstawę w doświadczeniach uzależnionego, wprowadza go do jego własnej sytuacji. Doświadczenia mają charakter duchowy, ale nie muszą być przyczyną nawrócenia i nagłej zmiany. Chodzi tu bardziej o proces drogi 12 kroków. Na płaszczyźnie przewidywania można poznać istnienie człowieka i Boga. Według Anonimowych Alkoholików człowiek uzależniony nie jest zdolny pomóc sam sobie w wyjściu z uzależnienia, jego własne siły są niewystarczające. Musi zgodzić się na istnienie wyższej siły niż on sam, a jest nią Bóg. Wyrażenie zgody przynosi uzależnionemu nadzieję na zbliżenie się do Boga i nawiązanie relacji z Nim. Nieważne to, jak człowiek Go określa, fundamentalna jest wiara jednostki w siłę większą niż ona sama. Przyjęcie prawdy o tej sile stanowi początek na drodze rozwoju duchowego. Anonimowi Alkoholicy nie są zależni od wiary czy Kościoła, ale nie są też przeciwko nim.

Dalsze kroki wprowadzają na drogę oczyszczenia osobistego. Zasady, jakimi kierują się Anonimowi Alkoholicy, korespondują z płaszczyzną norm i wartości wyjaśnionych w 12 krokach. Wynikiem oczyszczenia ma być pisemne udokumentowanie negatyw- 
nych emocji, np. gniewu, które przeżywa się względem ludzi, instytucji albo zasad. Uzewnętrzniona złość jest według Anonimowych Alkoholików przyczyną wielu problemów. Osobiste oczyszczenie nie pozostaje tylko $\mathrm{w}$ wersji papierowej, ale potrzebuje akceptacji i wymaga konsultacji z innym człowiekiem. Anonimowi Alkoholicy do pomocy w konfrontacji ze sobą samym polecają osobę duchowną albo człowieka upoważnionego z ramienia Kościoła lub zalecają wybranie sobie bliskiej osoby, do której ma się zaufanie. Po konfrontacji przychodzi ulga i możliwość doświadczenia bliskości Boga. Oczyszczenie nie jest zakończeniem procesu przemiany, ale początkiem dalszej pracy. Dlatego człowiek musi naprawić błędy, które popełnił, i znaleźć zranione przez siebie osoby, aby je przeprosić. W czasie realizacji kroków umocnienie można czerpać z obrzędowej modlitwy do Boga. Polecana ranna i wieczorna medytacja prowadzi do przemyśleń nad przeszłym i obecnym dniem i nad zachowaniami człowieka, nad tym, co da się ulepszyć. Kończy się ją modlitwą, prośbą do Boga o prowadzenie i pomoc w rozwiązywaniu problemów. Anonimowi Alkoholicy ostrzegają przed modlitwą ukierunkowaną na potrzeby własnego egoizmu. Jak twierdzą na podstawie 12 kroków, największą pomocą w abstynencji jest pomoc wyświadczona innym alkoholikom, która wypływa $\mathrm{z}$ wiary człowieka. W ramach tej pomocy należy szukać innych uzależnionych, pomagać im i dzielić się z nimi orędziem zawartym w 12 krokach. Pomoc ta utwierdza własną osobowość i przekonuje do pomocy drugim, a także oddziałuje na płaszczyźnie wspólnotowej $^{32}$.

Spotkania zaczyna, prowadzi i kończy ustanowiony sekretarz. Zazwyczaj rozpoczynają się one przywitaniem nowych uczestników. Kiedy ktoś chce zabrać głos, przedstawia się imieniem i wymienia mocného společenství Anonymních alkoholiků, Praha 2005, s. 448-501. 
swe uzależnienie. W ten sposób każdy uzależniony ma sobie uświadomić swoją słabość. Dalsze zasady spotkania dotyczą zwracania się do siebie po imieniu i zachowania anonimowości ${ }^{33}$. Ma się respektować mówcę bez przerywania mu i zadawania pytań. Uczestnicy uczą się cierpliwości, dyscypliny i zachowywania zasad komunikacji, aby był przestrzegany proces terapeutyczny. Dzielenie się doświadczeniami pozytywnie wpływa na innych członków, gdyż przypomina im ich własne wspomnienia i doświadczenia ${ }^{34}$. Po skończeniu opowiadania uczestnicy dziękują mówcy. Na otwartych spotkaniach mogą być obecni również nieuzależnieni, np. rodzina uczestnika, na zamknięte wstęp mają tylko członkowie AA. Na mityngi mogą przychodzić także osoby pod wpływem alkoholu, ale nie mają one prawa głosu. Przerwa pozytywnie wpływa na opadnięcie emocji uczestników i pomaga w lepszej koncentracji na długich spotkaniach. Podczas mityngu jest organizowana zbiórka na potrzeby grupy.

\section{Zakończenie}

Prezentowane metody w różny sposób wpływają na rozwój duchowości. Ich wykorzystanie potwierdza rzeczywistość oddziaływania na zmianę osobowości człowieka uzależnionego i na jego dalsze wzmocnienie. Rola duchowości jest najczęściej łączona z sensem życia i napełnieniem pustki wewnętrznej. Potrzeby duchowe silnie odżywają w sytuacji wejścia na drogę uwolnienia. Można również zaobserwować, że uzależnienie staje się dla człowieka duchowością pogłębiającą jego problemy i stan chorobowy. Pomoc w leczeniu uzależnień wymaga zmian na płaszczyźnie myślenia i zachowania, przy czym niezastąpione są poradnictwo i psychoterapia. Ich wspól-

\footnotetext{
33 Por. K. Nešpor, Návykové chování a závislost, dz. cyt., s. 176.

34 Por. K. Nešpor, Návykové chování a závislost, dz. cyt., s. 105.
} 
ne narzędzie stanowi relacja terapeutyczna i osoba terapeuty. Relacja ogranicza się do: zaufania, nadziei, rozwoju, komplementarności i bliskości osobowej. Terapeuta jest charakteryzowany jako osoba akceptująca, empatyczna i autentyczna ${ }^{35}$. Związek między duchowością a poradnictwem uwydatnia się w poradnictwie duchowym, które nie jest ograniczone tradycją, ale wychodzi naprzeciw duchowym potrzebom uzależnionych.

Wszystkie metody terapeutyczne są środkiem do szukania sensu życia i wchodzenia w relacje $\mathrm{z}$ innymi, szczególnie z najwyższym autorytetem. W każdej metodzie jest przestrzeń na osobiste rozumienie i przeżywanie sacrum. Duchowość w procesie leczenia uzależnień to element osobowości, który wpływa na jej powstanie i rozwój. Tak duchowość, jak i uzależnienie odnoszą się do całej tożsamości człowieka. 